\title{
Phantom Tumor with Real Tumor of The Lung: An Unreported Case
}

\author{
Fantom Tümörü ile Akciğerin Gerçek Tümörü: Bildirilmemiş Bir Olgu
}

Dilek Erdem? , İrem Karaman², Adem Dirican ${ }^{3}$, Şerket Özkaya ${ }^{4}$

\section{Abstract}

A phantom tumor of the lung is a localized collection of transudative interlobar pleural fluid in the settings of decompensated congestive heart failure that resembles a lung neoplasia on chest $X$-ray, but that vanishes after the appropriate diuretic therapy. Here, we report on a phantom tumor with a real lung neoplasia in the same location, both of which were contributing to the complaints and the clinical picture of the patient. Although phantom tumors are rare and should not be misdiagnosed as masses, it is worth making a further diagnosis and being cautious for possible neoplasia in the same setting. Since the coexistence of heart failure and lung cancer significantly changes the management and follow-up procedure of the patient, a multidisciplinary approach and elaborative work by the pulmonologist, oncologist and cardiologist is required on a case-by-case basis. In such patients, cardiotoxic chemotherapy agents should be avoided as a treatment to prevent the progression of heart failure. The present case confirms the rare possibility of the co-occurrence of lung neoplasia and phantom tumor, and recommends the delicate management of such patients.

Key words: Phantom tumor, lung cancer, congestive heart failure.

\section{Özet}

Akciğerde fantom tümörü, dekompanse konjestif kalp yetmezliği durumunda lokalize transüdatif interlobar plevral sıvı toplanması sonucu görülür ve akciğer grafisinde akciğer neoplazisine benzer kitle görünümüne sebep olur, ancak uygun diüretik tedavisinden sonra kaybolur. Burada, aynı lokasyonda gerçek bir akciğer neoplazisi ve fantom tümörünün görüldüğü ve bu iki durumun hastanın şikayetlerine ve klinik tablosuna neden olduğu bir olgu bildirdik. Fantom tümörleri nadir olarak görülür ve akciğerdeki kitle görünümüyle karıştırılmamalıdır, ancak olası durumlarda akciğer kanseri için temkinli olmak ve ileri testleri yapmak gerekir. Kalp yetmezliği ve akciğer kanseri birlikteliği hastanın yönetim ve takip prosedürünü önemli ölçüde değiştirdiğinden, münferit olgu bazında pulmonolog, onkolog ve kardiyologtan oluşan multidisipliner bir yaklaşım ve özenli bir çalışma gereklidir. Bu hastalarda kalp yetmezliğinin ilerlemesini önlemek için tedavi sırasında kardiyotoksik kemoterapi ajanlarından kaçınılmalıdır. Bu olgu, akciğer neoplazisinin fantom tümörü ile nadir olarak ortaya çıkma olasılığını doğrulamaktadır ve bu tür hastaların hassas yönetimine dikkat çekmektedir.

Anahtar Sözcükler: Fantom tümörü, akciğer kanseri, konjestif kalp yetmezliği.
'Department of Internal Medicine, Bahçeşehir University Faculty of Medicine, Division of Medical Oncology; Istanbul, Turkey; Department of Medical Oncology, VM Medical Park Samsun Hospital, Samsun, Turkey

${ }^{2}$ Bahcesehir University, School of Medicine, Istanbul, Turkey

${ }^{3}$ Department of Pulmonary Medicine, Samsun Medical Park Hospital, Samsun, Turkey

${ }^{4}$ Department of Pulmonary Medicine, Faculty of Medicine, Bahçeşehir University, Istanbul, Turkey

\author{
'Bahçeşehir Üniversitesi Tıp Fakültesi, Tıbbi Biyoloji Anabilim \\ Dalı, İstanbul \\ ${ }^{2}$ Bahçeşehir Üniversitesi Tıp Fakültesi, İstanbul \\ ${ }^{3}$ Samsun Medical Park Hastanesi Göğüs Hastalıkları \\ Bölümü, Samsun \\ ${ }^{4}$ Bahçeşehir Üniversitesi Tıp Fakültesi, Göğüs Hastalıkları \\ Anabilim Dalı
}

Submitted (Başvuru tarihi): 29.02.2020 Accepted (Kabul tarihi): 16.04.2020

Correspondence (iletişim): Dilek Erdem, Department of Internal Medicine, Bahçeşehir University Faculty of Medicine, Division of Medical Oncology; Istanbul, Turkey; Department of Medical Oncology, VM Medical Park Samsun Hospital, Samsun, Turkey

e-mail: dilekgurgenyatagi@yahoo.com

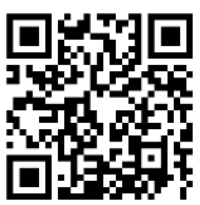


A phantom tumor of the lung is a localized collection of transudative interlobar pleural fluid in the settings of decompensated congestive heart failure that resembles a lung neoplasia on chest X-ray, but which vanishes after the appropriate diuretic therapy (1). Since it is a rare condition, awareness of this form of pleural effusion is crucial in the differential diagnosis of pulmonary masses (2). Here, we reported on a case with a phantom tumor and with a real lung tumor beneath it, in which both masses contributed to the appearance of a pulmonary mass in a chest $X$-ray.

\section{CASE}

A 78-year-old male patient with no history of hypertension or diabetes mellitus presented to the clinic with complaints of exertional dyspnea, dry cough, paroxysmal nocturnal dyspnea and angina. The patient had a history of three coronary angioplasty operations, and he was using clopidogrel, acetyl salicylic acid, atorvastatin, metoprolol, spironolactone and escitalopram at the time of admission.

In his first examination, his vitals were within the normal limits, with heart rate of 64 and blood pressure of 120/80 mmHg. After an echocardiography examination, he was diagnosed with grade III mitral insufficiency, accompanying grade III tricuspid insufficiency and pulmonary artery hypertension (pulmonary artery pressure $=65$ $\mathrm{mmHg}$ ). A chest examination revealed diminished pulmonary sounds and extensive rales in the base of both lungs. A pulmonary function test revealed a restrictive pattern. In posteroanterior chest X-ray, an enlarged cardiac silhouette with a bulky opacity in the right lung that was sharply marginated was found, consistent with a phantom tumor. (Figure 1) In a thorax HRCT, a phantom tumor in the interlobar fissure was seen, as a large mass. In addition, pericardial effusion with bilateral pleural fluids in the oblique fissure and in the pleural cavity was also reported (Figure 2). Laboratory tests showed no abnormal findings, and the sample from pleural fluid was consistent with transude. The diagnostic hypothesis was decompensated congestive heart failure in the presence of a phantom tumor of the lung.

Following hospitalization, no improvement was seen in the symptoms with IV diuretic treatment. The chest X-ray was repeated after the first 24 hours, but the phantom tumor was still present. Consequently, a thorax CT with PET scan was performed due to a suspicion of lung neoplasia. In the PET scan, a $45 \times 39 \mathrm{~mm}$ hypermetabolic mass was observed in the middle lobe of the right lung under the phantom tumor (Figure 3A). The phantom tumor (Figure 3B) did not indicate any FDG-uptake, while its right side demonstrated an increased FDG-uptake. Based on the findings, a tru-cut biopsy procedure was planned. The patient was discharged following the biopsy, but returned to the emergency room one week later with decompensated atrial fibrillation and ST elevation. The patient was admitted to the cardiovascular ICU and an amiodarone infusion was started. After one week of treatment with anti-arrhythmics and diuretics, the symptoms improved, and the patient was discharged until the results of the biopsy came through.

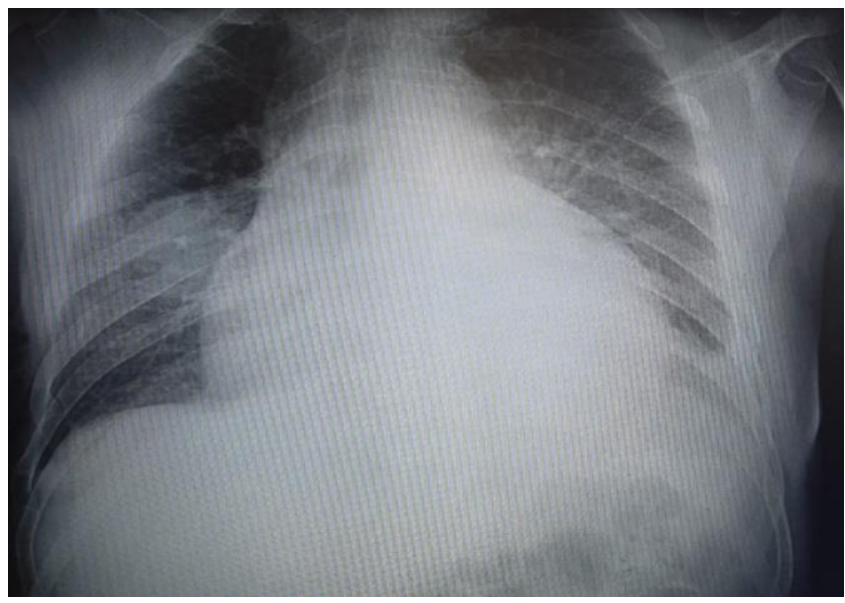

Figure 1: In the posteroanterior chest $X$-ray, enlarged cardiac silhouette with a bulky opacity in right lung which was sharply marginated was found, which was consistent with phantom tumor

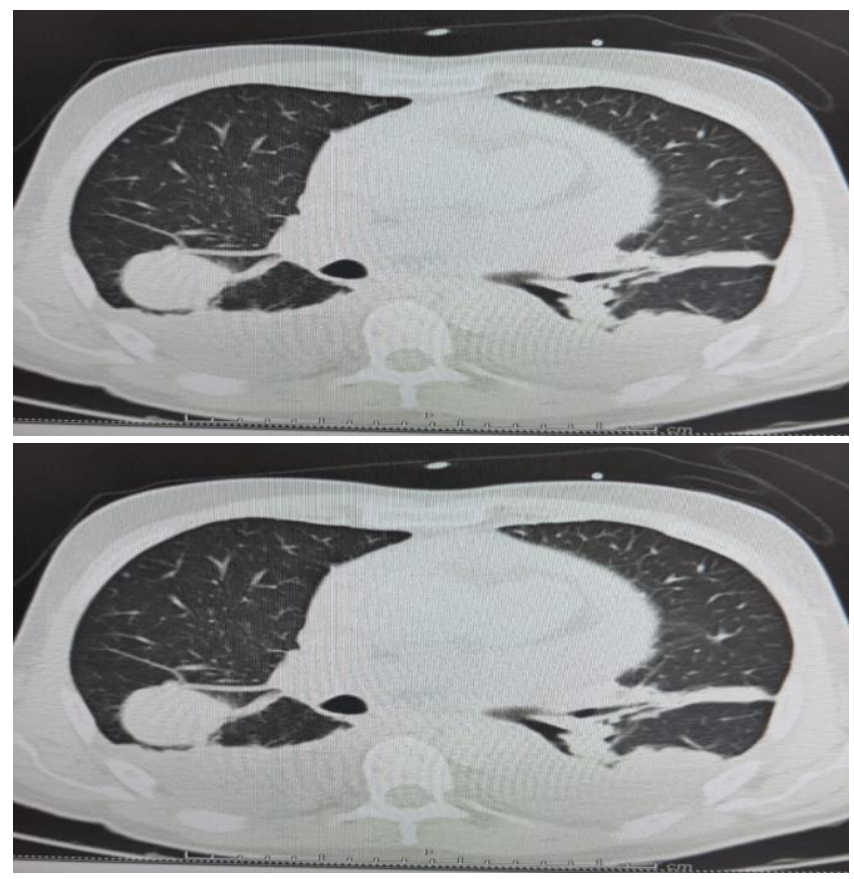

Figure 2: In thorax $C T$, a phantom tumor in the interlobar fissure in the appearance of a big mass has reported. A pericardial effusion with bilateral pleural fluids in oblique fissure and in pleural cavity has also reported 

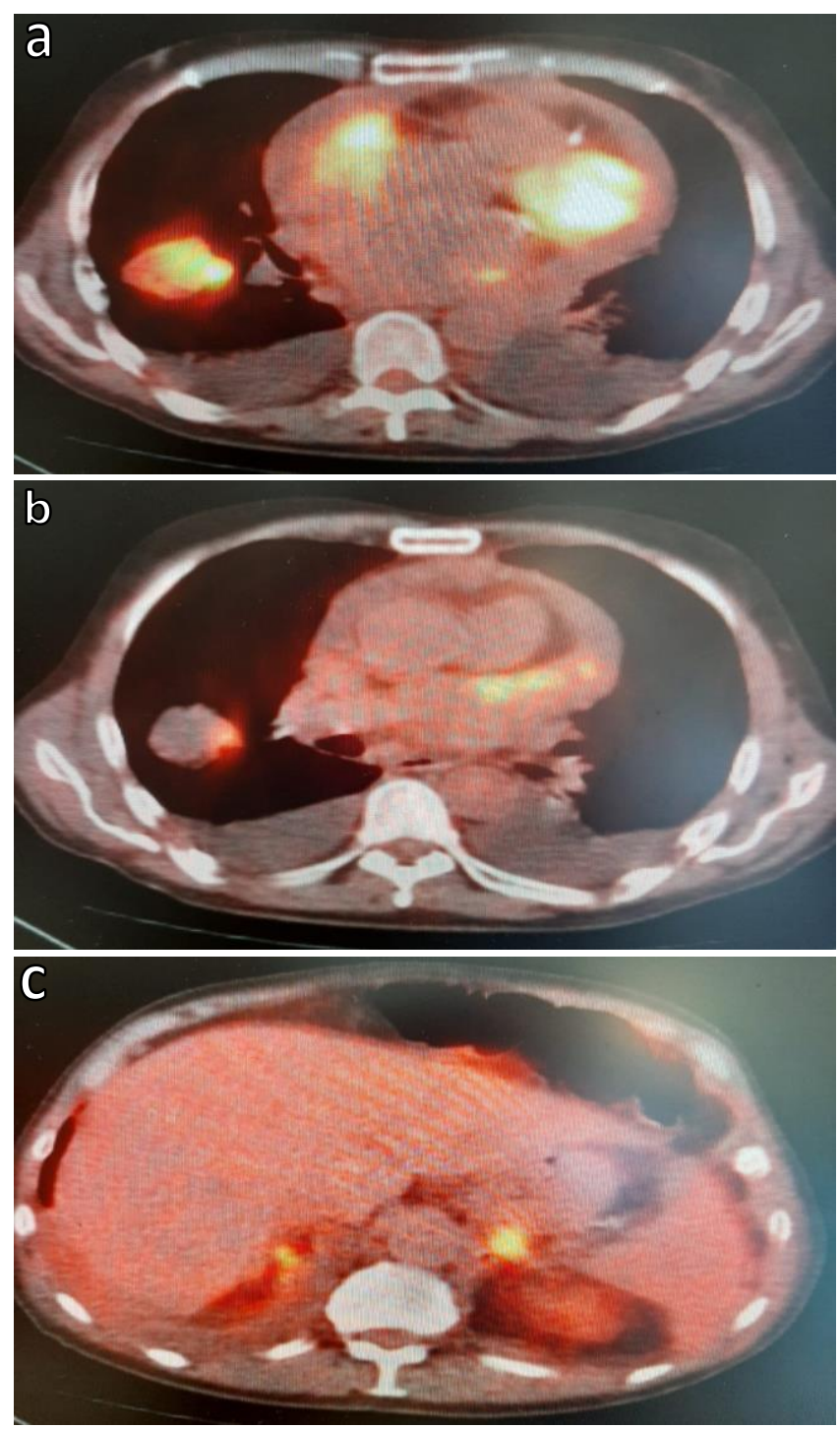

Figure 3: In PET scan, 45x39 mm hypermetabolic mass observed in middle lobe of the right lung under hypometabolic phantom tumor with bilateral pleural fluid (A), The phantom tumor did not indicate any FDGuptake, while its right side demonstrated an increased FDG-uptake which belongs to the tumor tissue (B), Hypermetabolic metastatic lesions were seen in bilateral adrenal glands (C)

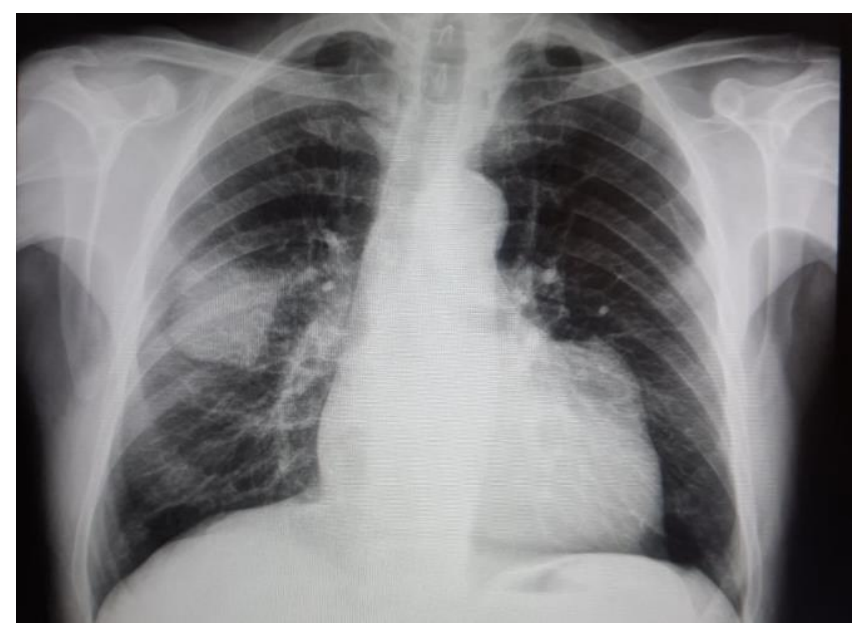

Figure 4: In chest $x$-ray after four months of immunotherapy and cardiac monitoring revealed the disappearance of phantom tumor with the real tumor under it
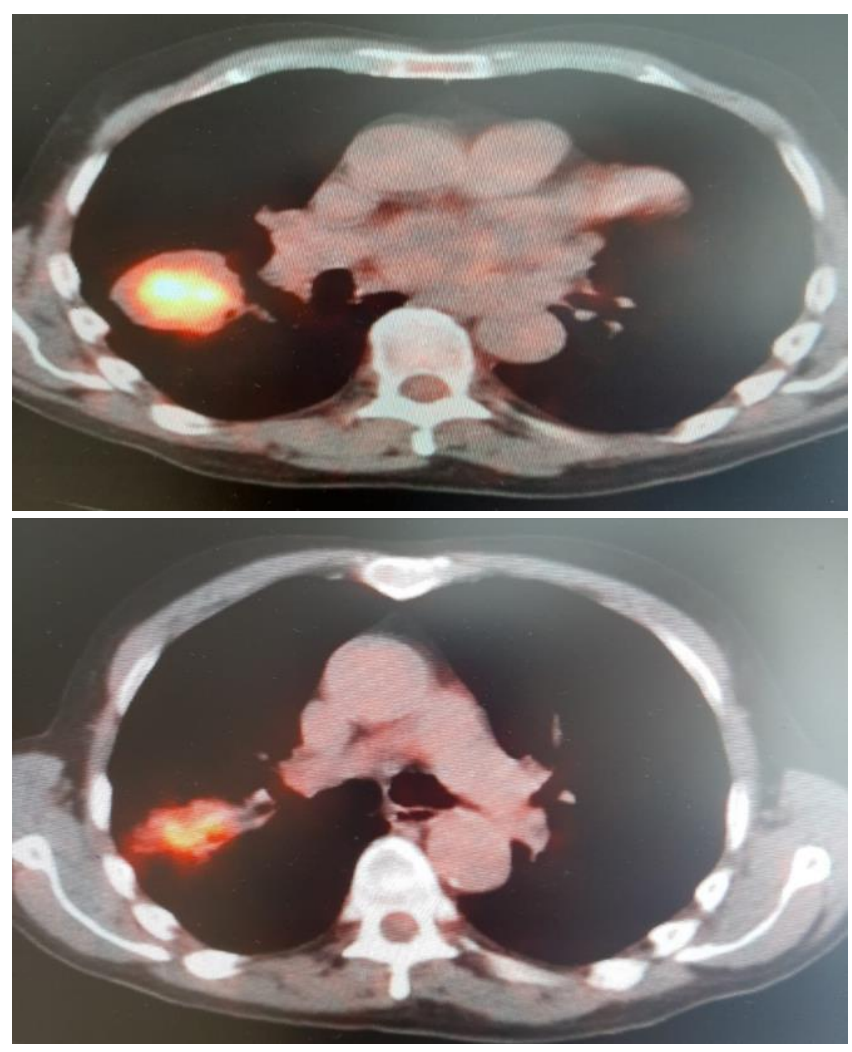

Figure 5: In PET-CT scan results after four months of treatment. Phantom tumor totally disappeared, and the PET scan revealed diminished pleural effusion with decreased hypermetabolic focuses

The biopsy results reported grade II adenocarcinoma of the lung with metastasis to the bilateral adrenal glands (Figure 3C) and increased PD-L 1 levels. At the same time, a left ventricular thrombus was identified upon admission to emergency room with night sweats, hemoptysis, angina and fever. After a final evaluation, a real tumor of the lung beneath the phantom tumor was diagnosed. The patient was prescribed with low molecular weight heparin for the left ventricular thrombus. The patient was hemodynamically stabilized, after which immunotherapy with nivolumab was started. After the two months of treatment, a chest $X$-ray and PET scan revealed a diminished pleural effusion with decreased hypermetabolic focus (Figure 4 and 5). In the fifth month, the patient's general status and symptoms have improved, and the exertional dyspnea and cough have resolved.

\section{DISCUSSION}

Literature contains few reports of phantom tumors of the lung, all of which resolved after the appropriate treatment $(1-6)$. The reported cases occurred predominantly in men, and commonly involved a transverse fissure of right lung (2). When the transudative fluid in the extravascular space is unable to pass into the pleural lymphatics properly due to pleuritis in decompensated heart failure, phantom 
tumors may appear, especially in the right lung, due to the higher hydrostatic pressure on the right side of the lung (5). A local increase in elastic recoil by the neighboring partially atelectatic lung, which is yielding the accumulation of fluid, is also considered responsible for the pathogenesis.

In most cases, phantom tumors appear in settings of congestive heart failure, although there may be other conditions, such as hypoalbuminemia, renal insufficiency or pleuritis (2). Accordingly, in the presence of accumulated pleural fluid within the fissure, a differential diagnosis should include transudates due to renal failure, exudates due to malignant effusions, benign asbestos-related effusions, parapneumonic effusions and hemothorax, chylothorax and fibrous tumors of the visceral pleura of the interlobar fissure (1).

Here, we reported on a phantom tumor with a real lung neoplasia in the same location, both of which contributed to the complaints and the clinical picture of the patient. As signs of congestive heart failure, the reported pericardial and pleural effusions in CT-scans led us to believe that decompensation had caused an accumulation of pleural fluid in the vascular spaces and the appearance of the mass. Although most case reports suggested no further investigation, and indicate an immediate launch of treatment $(2,4)$, the clinical picture of the patient should be carefully evaluated for further possible diagnoses, as in the presented case. We found in the present study that both pleural interlobar fluid and lung neoplasia were causing the symptoms and the chest $\mathrm{X}$-ray appearance. The presented case demonstrates the low possibility of the existence of lung neoplasia in an acute exacerbation of congestive heart failure settings.

The phantom tumors seen in congestive heart failure patients are a particularly important concern if the patient has a concurrent disease requiring treatment. In this case, the co-existence of heart failure and lung cancer significantly changed the management and follow-up of the patient. In such cases, the treatment course depends on crucial considerations and a multidisciplinary approach involving a pulmonologist, oncologist and cardiologist. Furthermore, each treatment procedure should be designed on a case-by-case basis. In such patients, cardiotoxic chemotherapy agents should be avoided in the course of treatment to prevent the progression of heart failure. Furthermore, a critical evaluation by a cardiologist should be carried out at every stage of treatment.

\section{CONCLUSION}

Phantom tumors are pseudo-tumors of the lung that are seen on chest $X$-rays in the setting of congestive heart failure. They often require no further investigation since, since they can resolve with appropriate diuretic treatments. However, a tight follow-up is required to ensure the disappearance of the mass. As in this the present case, there is the possibility of a real neoplasia of the lung being missed if the tumor appearance does not resolve following treatment. For this purpose, further investigations and imaging techniques, as well as biopsy procedures should be performed to ensure an accurate diagnosis. If lung cancer is discovered in such patients, the cardiologist and oncologist should collaborate in the establishment of an appropriate treatment while preventing the possible cardiac complications of chemotherapeutic agents. The present case confirms the rare possibility of the cooccurrence of lung neoplasia with a phantom tumor, and recommends the delicate management of such patients.

\section{CONFLICTS OF INTEREST}

None declared.

\section{AUTHOR CONTRIBUTIONS}

Concept - D.E., I.K., A.D., Ş.Ö.; Planning and Design D.E., I.K., A.D., Ş.Ö.; Supervision - D.E., I.K., A.D., S..Ö.; Funding - A.D., Ş.Ö., D.E.; Materials - Ş.Ö., D.E.; Data Collection and/or Processing - D.E., I.K.; Analysis and/or Interpretation - D.E., I.K.; Literature Review - D.E., Ş.Ö.; Writing - D.E., i.K., A.D., Ş.Ö.; Critical Review - D.E., I.K., A.D., Ş.Ö.

\section{YAZAR KATKILARI}

Fikir - D.E., I.K., A.D., Ş.Ö.; Tasarım ve Dizayn - D.E., I.K., A.D., Ş.Ö.; Denetleme - D.E., I.K., A.D., Ş.Ö.; Kaynaklar - A.D., Ş.Ö., D.E.; Malzemeler - Ş.Ö., D.E.; Veri Toplama ve/veya İşleme - D.E., I.K.; Analiz ve/veya Yorum - E D.E., I.K., N.K.; Literatür Taraması - D.E., Ş.Ö.; Yazıyı Yazan - D.E., I.K., A.D., Ş.Ö.; Eleştirel İnceleme D.E., I.K., A.D., S..Ö.

\section{REFERENCES}

1. Lozo M, Lozo Vukovac E, Ivancevic Z, Pletikosic I. Phantom tumor of the lung: localized interlobar effusion in congestive heart failure. Case Rep Cardiol 2014; 2014:207294. [CrossRef] 
2. Tesloianu DN, Chioarta $M$, Corduneanu D, Ignat $A M$, Petris AO, Tesloianu A. Does phantom tumor really exist? Maedica (Buchar) 2017; 12:281-5.

3. Ardic I, Yarlioglues M, Celik A, Kaya MG. Vanishing or phantom tumor of the lung. Tex Heart Inst J 2010; 37:730-1.

4. Melo BS, Serra AC, Belo MT, Belo Neto E, Melo SM. Phantom tumor of the lung. Rev Assoc Med Bras (1992) 2012; 58:517-8. [CrossRef]
5. Mikaeili H, Mehdizadeh Baghbani J. Multiple phantom tumor of the lung: A complex appearance resolving with appropriate intervention. Tanaffos 2016; 15:243-5.

6. Shaikh S, Shaikh S. Pleural effusion resembling a lung tumor: phantom tumor of the lung. Egypt J Intern Med 2016; 28:174-5. [CrossRef] 